Trimo Susilo : Pengembangan Pembelajaran Inquiry Bervisi Sets Pada Sistem Pencernaan untuk Meningkatkan Kecerdasan Emosional dan Prestasi Belajar

\title{
PENGEMBANGAN PEMBELAJARAN INQUIRY BERVISI SETS PADA SISTEM PENCERNAAN UNTUK MENINGKATKAN KECERDASAN EMOSIONAL DAN PRESTASI BELAJAR
}

\section{Trimo Susilo}

SMAN 3 Pekalongan, e-mail: abimtrims@gmail.com

\begin{abstract}
Attention to the issue of education is still lacking emotional intelligence development, but success is not determined by intelligence (IQ) alone, but rather by the emotional intelligence (EQ). Science learning process using appropriate methods and approaches can improve emotional intelligence. Therefore the development of research inquiry learning SETS vision on the concept of the digestive tract. The purpose of research for new product development, testing the validity and effectiveness of the product in improving EQ and student achievement. Research methods research and development $(R$ and $D)$. Limited scale test was conducted in a classroom, using one single shot design case study. Large scale test was conducted in a control class, and two experimental class, using pretest-posttest designs control group. Research subjects in class XI Science SMAN 3 Pekalongan. Test results show a valid product (criterion> 0.81 ), the percentage achieving grades EQ experimental class > class control. $T$ test results showed $t=42.681>t$ table $=2.025$. Achievement of learning experimental class $>$ class control. Conclusions of research, product development of valid and effective for improving EQ and student achievement. Products recommended to be a reference device development and learning to improve student achievement $E Q$.
\end{abstract}

Keywords: Learning Inquiry, SETS, Emotional Intelligence

\begin{abstract}
ABSTRAK
Perhatian dunia pendidikan terhadap pengembangan kecerdasan emosional masih kurang, padahal kesuksesan tidak ditentukan oleh kecerdasan intelektual (IQ) saja, tetapi lebih oleh kecerdasan emosional (EQ). Proses pembelajaran menggunakan metode maupun pendekatan yang tepat dapat meningkatkan EQ. Oleh karena itu dilakukan penelitian pengembangan perangkat pembelajaran inquiry bervisi SETS pada konsep sistem pencernaan makanan. Tujuan penelitian untuk pengembangan produk baru, pengujian validitas dan efektivitas produk dalam meningkatkan EQ dan prestasi belajar. Penelitian menggunakan metode penelitian dan pengembangan $(R$ and $D)$. Ujicoba skala terbatas dilakukan pada satu kelas, desain single one shot case study. Ujicoba skala luas dilakukan pada satu kelas kontrol, dan dua kelas eksperimen, desain pretest-posttest control group design. Subjek penelitian siswa kelas XI IPA di SMA Negeri 3 Pekalongan. Hasil ujicoba menunjukkan produk valid (kriteria > 0,81), pencapaian persentase nilai EQ kelas eksperimen > kelas kontrol. Hasil uji t menunjukkan t hitung
\end{abstract}


$=42,681>\mathrm{t}$ tabel $=2,025$. Pencapaian prestasi belajar kelas eksperimen $>$ kelas kontrol. Simpulan penelitian, produk pengembangan valid dan efektif untuk meningkatkan EQ dan prestasi belajar siswa. Produk direkomendasikan menjadi acuan pengembangan perangkat pembelajaran untuk meningkatkan EQ dan prestasi belajar siswa.

Kata kunci: Pembelajaran Inquiry, SETS, Kecerdasan Emosional (EQ).

\section{PENDAHULUAN}

Perhatian dunia pendidikan terhadap persoalan pengembangan kecerdasan emosional masih kurang, padahal UU RI No. 20 Tahun 2003 telah mengamanatkan kepada semua lembaga pendidikan di Indonesia untuk mengembangkan kecerdasan intelektual (IQ), maupun kecerdasan emosional (EQ). Kecerdasan emosional memberi kontribusi besar pada kesuksesan seseorang (Chaturvedi, 2011; Goleman, 2006; Agustian, 2003; Gottman, 2001). Oleh karena itu upaya pengembangan kecerdasan emosional perlu dilakukan secara sistematis dan berkelanjutan melalui pendidikan.

Menurut Wakil Presiden Budiono (Suara Merdeka: 17 Oktober 2012), manusia yang berkualitas harus memiliki kecerdasan intelektual dan kecerdasan emosional yang tinggi, tetapi sangat disayangkan belum ada yang memberi tempat dan bobot yang tepat bagi pengajar kecerdasan emosional, sehingga perlu dilakukan pengkajian kembali apakah substansi, cara pengajaran, dan sistem penilaian pendidikan sudah berjalan dengan baik.

Hakekat sains tidak hanya produk, tetapi juga mengandung banyak muatan nilai yang dikenal dengan sikap ilmiah. Proses pembelajaran sains dengan menggunakan metode maupun pendekatan yang tepat dapat meningkatkan kecerdasan emosional siswa. Pada kurikulum 2006 dijelaskan bahwa pendidikan sains berkaitan dengan cara mencari tahu (inquiry) tentang alam secara sistematis. Proses pembelajaran sains bukan hanya sebagai upaya penguasaan kumpulan pengetahuan berupa fakta, konsep, atau prinsip saja tapi juga merupakan suatu proses penemuan. Oleh karena itu proses pembelajaran sains sebaiknya diarahkan untuk inquiry, sehingga siswa akan mendapatkan pemahaman yang lebih baik mengenai sains, dan akan lebih tertarik terhadap sains jika mereka dilibatkan secara aktif dalam "melakukan" sains, serta menumbuhkan sikap ilmiah (Yager, 2010; Trianto, 2009; Sanjaya, 2008; Widyasari, 2007; Garton, 2005). 
Salah satu pendekatan dalam pembelajaran sains yang tepat dalam meningkatkan kecerdasan emosional adalah pembelajaran bervisi SETS. Pada kurikulum 2006, pendekatan SETS disebut dengan pendekatan salingtemas. Cara pembelajaran ini memfasilitasi siswa melakukan penyelidikan untuk mendapatkan pengetahuan yang berkaitan dengan empat unsur yaitu sains, lingkungan, teknologi, dan masyarakat. Pendekatan SETS membantu penguasaan konsep IPA secara integratif, kontekstual, dan aplikatif. Oleh karena itu, pengintegrasian pendidikan kecerdasan emosional dalam proses pembelajaran ini lebih mudah, dengan cara siswa secara aktif diajak mengamati dan berdiskusi menyelesaikan masalah-masalah yang diperkirakan akan timbul di sekitar kehidupannya. (Ragil, 2011; Binadja, 2002)

Hasil studi lapangan menunjukkan pembelajaran biologi di SMA/MA Kota Pekalongan belum memperhatikan pendidikan kecerdasan emosional siswa, banyak menggunakan metode ceramah dan kurang melibatkan peran aktif siswa, pembelajaran bersifat konseptual. Setelah dilakukan kegiatan identifikasi perangkat pembelajaran ternyata perangkat pembelajaran belum memfasilitasi siswa untuk meningkatkan kecerdasan emosional, belum tersedia perangkat pembelajaran inquiry bervisi SETS pada konsep biologi untuk meningkatkan kecerdasan emosional siswa.

Berdasarkan identifikasi masalah di atas dan rumusan masalah, maka tujuan dari penelitian ini adalah: 1). Mengembangkan perangkat pembelajaran inquiry bervisi SETS pada konsep sistem pencernaan makanan yang tepat untuk meningkatkan kecerdasan emosional dan prestasi belajar siswa; 2). Menentukan validitas perangkat pembelajaran inquiry bervisi SETS pada konsep sistem pencernaan makanan dalam meningkatkan kecerdasan emosional dan prestasi belajar siswa; 3). Menentukan efektivitas perangkat pembelajaran inquiry bervisi SETS pada konsep sistem pencernaan makanan dalam meningkatkan kecerdasan emosional dan prestasi belajar siswa.

Kecerdasan Emosional menurut Goleman (2006) adalah kemampuan seseorang dalam mengatur emosi, menjaga keselarasan emosi, dan pengungkapan emosinya melalui kemampuan untuk mengenali emosi diri, mengelola emosi, memotivasi diri sendiri, mengenali emosi orang lain (empati), dan kemampuan untuk membina hubungan (kerjasama) dengan orang lain. Menurut Goleman (2006), bila seseorang memiliki kecerdasan intelektual tinggi namun kecerdasan emosionalnya rendah maka cenderung akan terlihat sebagai 
orang yang keras kepala, sulit bergaul, mudah frustrasi, tidak mudah percaya kepada orang lain, tidak peka dengan kondisi lingkungan dan cenderung putus asa bila mengalami stress. Kondisi sebaliknya, dialami oleh orang-orang yang memiliki kecerdasan intelektual rata-rata namun memiliki kecerdasan emosional yang tinggi. Kecerdasan emosional bukan faktor genetik yang diperoleh sejak lahir, tetapi merupakan bentuk keterampilan yang membutuhkan proses panjang dalam mempelajarinya dan lingkungan yang kondusif dalam pembentukannya. Melalui pendidikan siswa dapat diajarkan keterampilan dasar kecerdasan emosional, sehingga secara emosional akan lebih cerdas, penuh pengertian, mudah menerima perasaan-perasaan, dan lebih banyak pengalaman dalam memecahkan permasalahannya sendiri. Pada usia remaja akan memberikan lebih banyak kesuksesan di sekolah, dan dalam berhubungan dengan rekan-rekan sebaya, serta akan terlindung dari resiko-resiko seperti obat-obat terlarang, kenakalan remaja, tindak kekerasan, serta seks yang tidak aman. (Gottman, 2001).

Metode pembelajaran inquiry merupakan salah satu metode yang penting dalam pembelajaran sains, yang dapat mengembangkan keterampilan berpikir kritis dan sistematik, kemampuan memecahkan masalah, dan kreatifitas siswa. Trianto (2009) menyatakan bahwa inkuiri tidak hanya mengembangkan kemampuan intelektual tetapi seluruh potensi yang ada, termasuk pengembangan emosional dan keterampilan. Menurut Yager \& Akcay (2010), inquiry merupakan pendekatan untuk mengajar sebagaimana tindakan para ilmuwan dalam melakukan penyelidikan ilmu, dan dapat menjadi metode pengajaran yang efektif, yang dapat membantu siswa memahami konsep, dan penggunaan ketrampilan proses. Menurut Sanjaya (2008), strategi pembelajaran inquiry adalah rangkaian kegiatan pembelajaran yang menekankan proses berfikir secara kritis dan analitis untuk mencari dan menemukan sendiri jawaban dari suatu masalah yang dipertanyakan. Langkah-langkah pembelajaran inquiry adalah sebagai berikut: 1). Orientasi, Guru menciptakan suasana atau iklim pembelajaran yang responsif, misalnya dengan cara guru merangsang dan mengajak siswa berfikir memecahkan suatu masalah yang kontekstual; 2). Merumuskan masalah, Guru memberi masalah atau persoalan yang menantang, siswa didorong mencari jawaban yang tepat. Melalui proses ini siswa akan memperoleh pengalaman yang berharga sebagai upaya mengembangkan mental melalui proses berfikir; 3). Merumuskan hipotesis, potensi untuk 
mengembangkan kemampuan menebak atau berhipotesis setiap siswa perlu dibina, misalnya dengan cara guru mengajukan pertanyaan yang mendorong siswa untuk merumuskan jawaban sementara yang harus bersifat rasional dan logis; 4). Mengumpulkan data, aktivitas siswa menjaring informasi yang dibutuhkan untuk menguji hipotesis yang diajukan. Proses ini sangat penting dalam mengembangkan intelektual siswa, dan guru dapat memfasilitasi siswa dalam mencari informasi yang dibutuhkan; 5). Menguji hipotesis, proses ini melatih siswa mengembangkan kemampuan berfikir rasional karena kebenaran jawaban yang diberikan berdasarkan argumentasi dengan data yang diperoleh dan dapat dipertanggungjawabkan; 6). Merumuskan kesimpulan, proses mendeskripsikan temuan yang diperoleh berdasarkan pengujian hipotesis.

Inquiry sebagai salah satu metode pembelajaran sains memiliki beberapa kelebihan maupun kelemahan dalam pelaksanaannya di lapangan. Beberapa kelebihan pembelajaran inquiry menurut Sanjaya (2008) antara lain: 1). Menekankan pada pengembangan aspek kognitif, afektif, dan psikomotor secara seimbang sehingga pembelajaran lebih bermakna; 2). Memberi ruang kepada siswa untuk belajar sesuai dengan gaya belajar mereka sendiri; 3). Pembelajaran inquiry sesuai dengan perkembangan psikologi modern yang menganggap belajar adalah proses perubahan tingkah laku berkat adanya pengalaman; 4). Pembelajaran inquiry memberikan pelayanan kebutuhan siswa yang memiliki kemampuan belajar berbeda-beda. Beberapa kelemahan pembelajaran inquiry menurut Sanjaya (2008) antara lain: 1). Kesulitan mengontrol kegiatan dan keberhasilan siswa selama proses pembelajaran; 2). Kesulitan menyesuaikan pelaksanaan dengan perencanaan pembelajaran karena terbentur dengan kebiasaan siswa dalam belajar; 3). Memerlukan waktu yang panjang dalam mengimplementasikan pembelajaran, sehingga ada kesulitan dengan pengelolaan waktu.

Pembelajaran bervisi SETS adalah pembelajaran integratif untuk mengaitkan setiap konsep dengan keempat unsur SETS yaitu sains, lingkungan, teknologi, dan masyarakat (salingtemas), sehingga dapat diperoleh pemahaman yang lebih mendalam. Pengajaran SETS fokus mengupayakan siswa agar dapat melakukan penyelidikan untuk mendapatkan pengetahuan yang berkaitan dengan salingtemas. Siswa diminta melakukan penyelidikan, berarti memberi kesempatan kepada siswa untuk mengembangkan lebih jauh pengetahuan yang telah mereka peroleh agar mereka dapat menyelesaikan masalah-masalah yang 
diperkirakan akan timbul di sekitar kehidupannya. Pengajaran SETS nampaknya bukanlah suatu tugas yang ringan bagi guru, tetapi pengajaran ini sangat berguna dan patut diberi perhatian (Binadja, 1999b). Pada pembelajaran biologi bervisi SETS, memiliki beberapa ciri (Binadja, 2002) yaitu: 1). Pembelajaran kontekstual; 2). Pemanfaatan konsep sains ke bentuk teknologi untuk kepentingan masyarakat; 3). Analisis dampak proses pentransferan konsep sains ke bentuk teknologi; 4). Menjelaskan hubungan antara konsep sains dengan unsur-unsur lain dalam SETS yang mempengaruhi berbagai keterkaitan antar unsur tersebut; 5). Analisis manfaat atau kerugian penggunaan konsep sains bila diubah dalam bentuk teknologi; 5). Konstruktivisme, yaitu siswa diajak berbincang tentang SETS dari berbagai macam arah dan titik awal bergantung pada pengetahuan dasar siswa. Pembelajaran biologi bervisi SETS dalam pengembangan kurikulum biologi mampu meningkatkan kecerdasan intelektual dan kecerdasan emosional. Pada proses pembelajaran bervisi SETS mensyaratkan pengintegrasian berbagai pengetahuan yang telah dipelajari oleh siswa untuk dapat diaplikasikan dalam bentuk teknologi. Teknologi tersebut harus dapat mensejahterakan masyarakat tanpa merusak lingkungan fisik maupun mental, dari bidang manapun siswa memfokusi ilmunya. Oleh karena itu, produk pembelajaran bervisi SETS adalah siswa yang memiliki kemampuan penalaran analitis dan sintesis, kreatif, inovatid, dan inventif, serta produktivitas yang tinggi (Binadja, 1999a).

\section{METODE}

Metode pengembangan yang digunakan dalam penelitian adalah metode penelitian dan pengembangan (education research and development). Prosedur penelitian yang digunakan mengacu pada prosedur penelitian pengembangan yang dikembangkan oleh Sugiyono (2010). Penelitian ini meliputi: 1). Tahap studi pendahuluan; 2). Tahap studi pengembangan yaitu melakukan pengembangan produk baru berupa perangkat pembelajaran inquiry bervisi SETS pada konsep sistem pencernaan makanan; 3). Tahap evaluasi yaitu melakukan pengujian validitas maupun efektivitas produk.

Subyek uji coba dalam penelitian ini adalah siswa kelas XI IPA di SMA Negeri 3 Pekalongan tahun pelajaran 2012-2013 sebanyak 118 orang, yang terdiri atas 4 kelas, satu kelas digunakan untuk uji coba perangkat pembelajaran dalam skala terbatas, sedangkan untuk uji coba dalam skala luas menggunakan 3 kelas 
lainya, yaitu 2 kelas eksperimen dan 1 kelas kontrol. Pada tahap uji coba dalam penelitian ini dilakukan kegiatan pembelajaran yang sesungguhnya, yaitu menerapkan perangkat pembelajaran yang telah dikembangkan pada tahap sebelumnya (develope).

Jenis data yang diperoleh meliputi data kuantitatif dan data kualitatif dari berbagai sumber. Data kuantitatif berupa nilai prestasi prestasi belajar siswa yang diperoleh dari lembar soal pre test dan post test, lembar penilaian unjuk kerja, dan LKS. Data kualitatif berupa hasil validasi perangkat pembelajaran dan instrumen penelitian, nilai kecerdasan emosional siswa yang diperoleh dari lembar observasi dan angket kecerdasan emosional.

Instrumen pengumpul data yang digunakan meliputi: 1). Lembar penilaian perangkat pembelajaran untuk mengetahui validitas perangkat yang telah dikembangkan; 2). Lembar penilaian kecerdasan emosional berupa lembar observasi selama proses pembelajaran, dan lembar angket pada akhir kegiatan pembelajaran; 3). Asesmen pembelajaran berupa lembar soal pre test dan post test, lembar penilaian unjuk kerja, dan LKS.

Validitas perangkat pembelajaran dalam penelitian ini dilakukan oleh lima validator berupa validitas isi (content validity), yaitu validitas yang diperoleh setelah dilakukan penganalisaan, penelusuran atau pengujian sesuai isi kurikulum (Sugiyono, 2010). Analisis data dilakukan secara deskriptif. Analisis data penilaian kecerdasan emosional siswa dilakukan secara deskriptif persentase. Analisis data prestasi belajar siswa dianalisis dengan cara: 1). Menghitung tingkat ketuntasan belajar secara klasikal pada kelas eksperimen dan kelas kontrol; 2). Menghitung peningkatan prestasi belajar pre test dan post test kelas eksperimen dan kelas kontrol dengan menggunakan rumus gain ternormalisasi atau N-gain; 3). Membandingkan rata-rata prestasi belajar kelas eksperimen dengan kelas kontrol menggunakan uji t.

\section{HASIL DAN PEMBAHASAN}

\section{Hasil Validasi Perangkat Pembelajaran}

Validitas perangkat pembelajaran setiap jenis produk perangkat pengembangan ditentukan berdasarkan nilai rata-rata hasil validasi lima validator. Berdasarkan hasil analisis rata-rata nilai hasil validasi setiap jenis 
perangkat (Gambar 4.1), semua jenis perangkat pembelajaran sangat valid karena kategori instrumen berada pada kriteria lebih dari 0,81 .

\begin{tabular}{|l|}
\hline$\square$ Silabus \\
$\square$ RPP \\
$\square$ Bahan Ajar \\
$\square$ LKS \\
$\square$ Soal Evaluasi \\
$\square$ Penilaian EQ
\end{tabular}

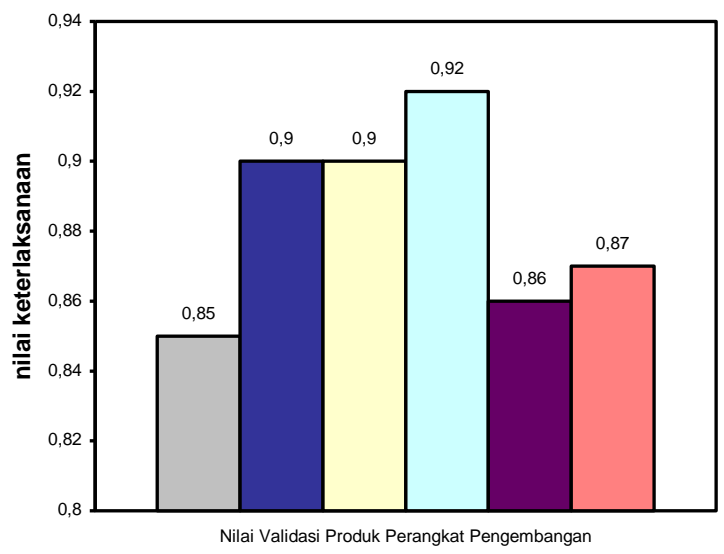

Gambar 4.1 Diagram Nilai Hasil Validasi Produk Perangkat Pengembangan

Tingkat validitas jenis produk perangkat pengembangan ternyata bervariasi, nilai tertinggi terdapat pada instrumen LKS dan nilai terendah terdapat pada instrumen silabus. Perbaikan perangkat pembelajaran secara umum mencakup keterkaitan unsur SETS dan kecerdasan emosional yang seharusnya dibahas secara menyeluruh pada semua jenis perangkat pembelajaran. Alat evaluasi juga mengalami revisi, sehingga dapat digunakan untuk mengukur peningkatan kecerdasan emosional maupun prestasi belajar siswa.

\section{Hasil Observasi Nilai Kecerdasan Emosional Siswa}

Ketercapaian persentase nilai rata-rata kecerdasan emosional yang paling tinggi ditunjukkan pada kelas eksperimen, dan terendah pada kelas kontrol. Nilai kecerdasan emosional pada kelas skala terbatas lebih rendah dibandingkan kelas eksperimen namun cenderung lebih tinggi dibandingkan kelas kontrol. Nilai kecerdasan emosional siswa ditunjukkan pada Gambar 4.2. 


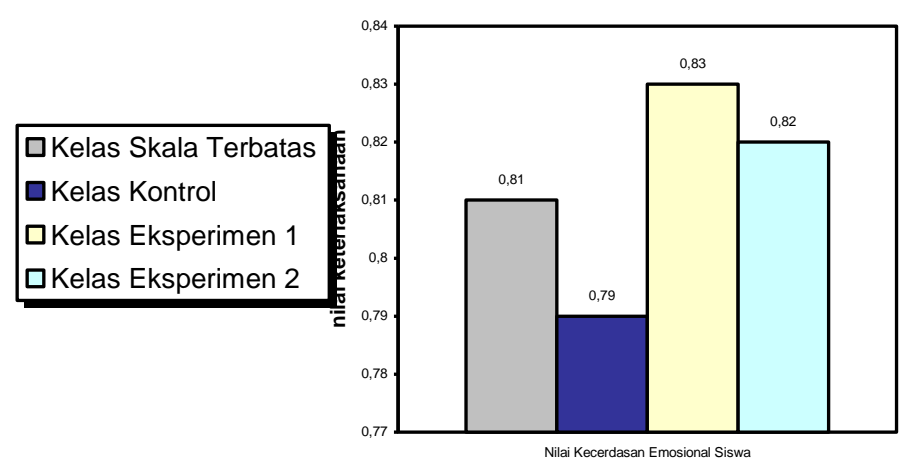

Gambar 4.2. Diagram Ketercapaian Nilai Kecerdasan Emosional Siswa

Pada ujicoba skala luas, persentase nilai rata-rata kecerdasan emosional siswa pada kelas eksperimen berada pada kriteria sangat tinggi ( $83 \%$ dan $82 \%$ ), sedangkan pada kelas kontrol pada kriteria tinggi (79\%). Hasil uji t menunjukkan nilai $\mathrm{t}$ hitung $=42,681>\mathrm{t}$ tabel $=2,025$ atau berada pada daerah penolakan Ho, maka dapat disimpulkan bahwa nilai rata-rata kecerdasan emosional siswa kelas eksperimen berbeda secara signifikan dengan kelas kontrol, dalam hal ini kelas eksperimen lebih baik dari pada kelas kontrol.

Nilai kecerdasan emosional pada penelitian ini hanya diamati pada aspek kreativitas, motivasi diri, empati, kemampuan kerja sama, dan kemampuan komunikasi. Hasil penelitian menunjukkan adanya perbedaan nilai dari kelima aspek tersebut sebagaimana ditunjukkan pada Gambar 4.3.

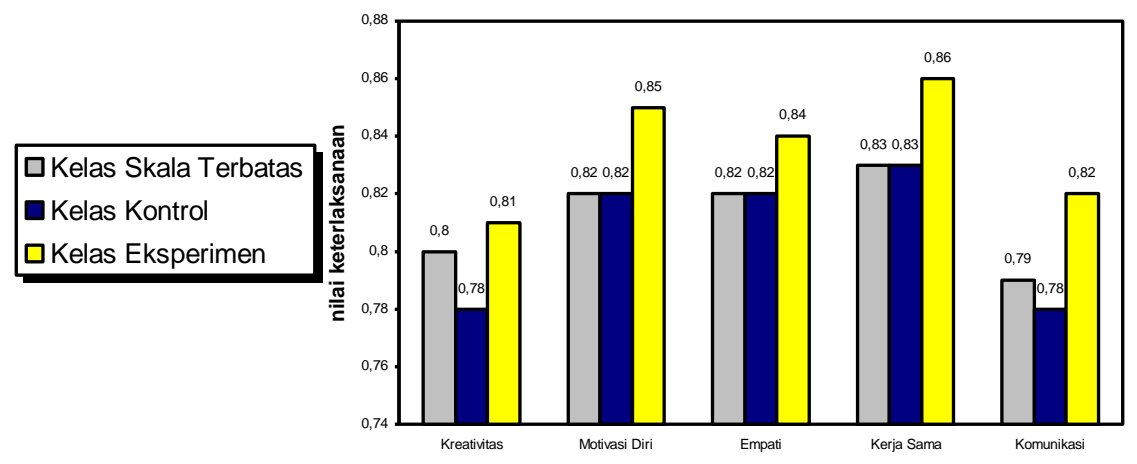

Gambar 4.3. Diagram Pencapaian Setiap Aspek Kecerdasan Emosional Siswa 
Pencapaian nilai kecerdasan emosional kelas eksperimen pada semua aspek ternyata lebih tinggi dibandingkan kelas kontrol, terutama pada aspek kerja sama. Nilai kecerdasan emosional pada kelas skala terbatas pada semua aspek lebih rendah dibandingkan kelas eksperimen namun cenderung lebih tinggi dibandingkan kelas kontrol, kecuali pada aspek motivasi diri, empati, dan kerja sama memperoleh nilai yang sama dengan kelas kontrol.

\section{Hasil Observasi Prestasi belajar Siswa}

Efektivitas perangkat pembelajaran dalam meningkatkan prestasi belajar siswa dapat diketahui dari hasil analisis data prestasi belajar siswa untuk mengetahui: 1). Ketuntasan belajar siswa secara klasikal; 2). Nilai rata-rata hasil tes pada kelas eksperimen lebih besar dari kelas kontrol; 3). Ketercapaian peningkatan prestasi belajar ( $\mathrm{N}$ - gain)

Ketercapaian prestasi belajar siswa yang paling tinggi ditunjukkan pada kelas eksperimen, dan terendah pada kelas kontrol. Ketercapaian prestasi belajar pada kelas skala terbatas lebih rendah dibandingkan kelas eksperimen namun cenderung lebih tinggi dibandingkan kelas kontrol. Rekapitulasi persentase ketuntasan belajar, tingkat capaian $\mathrm{N}$-gain, dan perbandingan nilai rata-rata prestasi belajar siswa kelas skala terbatas, kelas kontrol dan kelas eksperimen dapat dilihat pada Gambar 4.4..

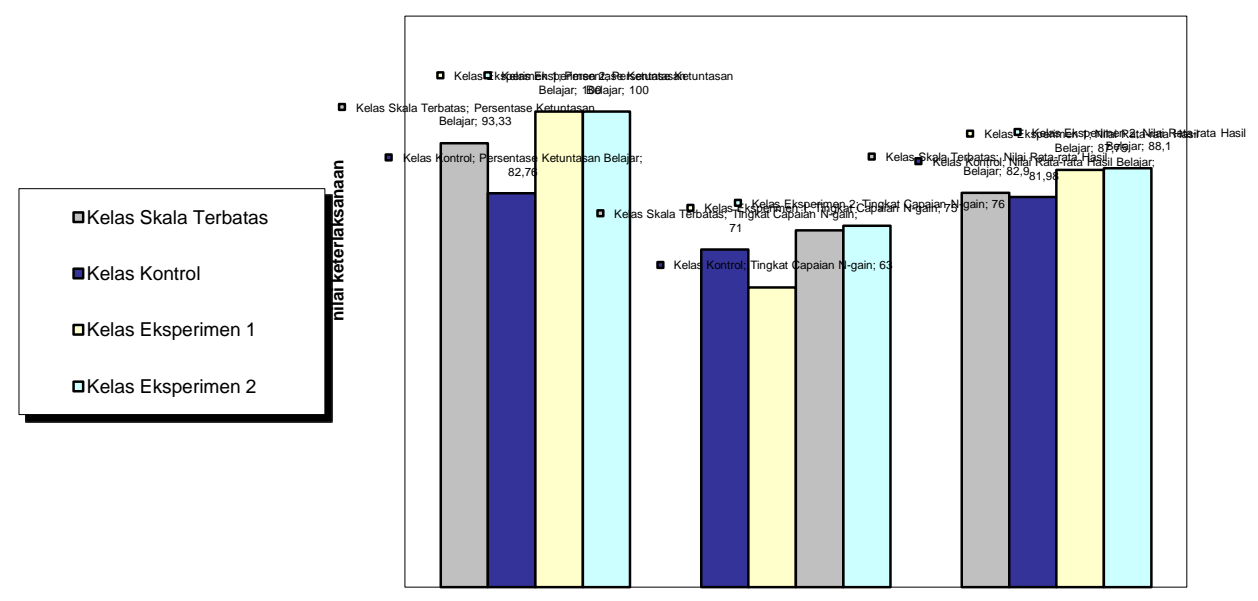

Gambar 4.4. Diagram Ketercapaian Nilai Prestasi belajar Siswa 
Pada ujicoba skala luas, ketercapaian prestasi belajar siswa: 1). Pada kelas eksperimen ketuntasan belajar dicapai oleh seluruh siswa, pada kelas kontrol terdapat 5 dari 29 siswa tidak tuntas belajar; 2). Peningkatan prestasi belajar pada kelas eksperimen termasuk katagori tinggi $(0,78$ dan 0,79$)$, sedangkan pada kelas kontrol termasuk katagori sedang $(0,64)$; 3$)$. Nilai rata-rata hasil tes kelas eksperimen mencapai 89,40 dan 89,55, pada kelas kontrol hanya 82,21.

Hasil uji t ketuntasan pada kelas eksperimen, diperoleh nilai $\mathrm{t}$ hitung $=$ $34,375>\mathrm{t}$ tabel $=2,002$, artinya persentase siswa yang telah mencapai nilai KKM lebih dari 75\%. Hasil uji t-beda rerata nilai diperoleh nilai $\mathrm{t}$ hitung $=52,446>\mathrm{t}$ tabel $=1,988$, artinya terdapat perbedaan nilai rata-rata yang signifikan yaitu kelas eksperimen lebih baik dari kelas kontrol.

\section{Pembahasan Produk Pengembangan}

Perangkat pembelajaran inquiry bervisi SETS pada kosep sistem pencernaan makanan yang dikembangkan telah memenuhi kriteria sangat valid berdasarkan validasi oleh para ahli. Hasil validasi menunjukkan nilai semua jenis perangkat pembelajaran $\geq 0,81$ yang berarti jauh diatas kriteria minimal untuk dikatakan valid yaitu 0,63 .

Perangkat pembelajaran yang dikembangkan menggunakan metode pembelajaran inquiry, berpendekatan SETS, dan mengintegrasikan pendidikan kecerdasan emosional. Karakteristik pembelajaran inquiry, pembelajaran SETS, dan pengintegrasian pendidikan kecerdasan emosional seharusnya selalu tampak pada semua jenis perangkat pembelajaran yang dikembangkan Pada penelitian ini karakteristik ketiga komponen dasar tersebut baru tampak dengan jelas di dalam LKS, sedangkan pada silabus, RPP, bahan ajar, dan alat evaluasi hasil pengembangan masih perlu penyempurnaan lagi. Model pengorganisasian proses pembelajaran inquiry bervisi SETS pada konsep sistem pencernaan makanan hasil pengembangan disajikan pada Gambar 4.5 


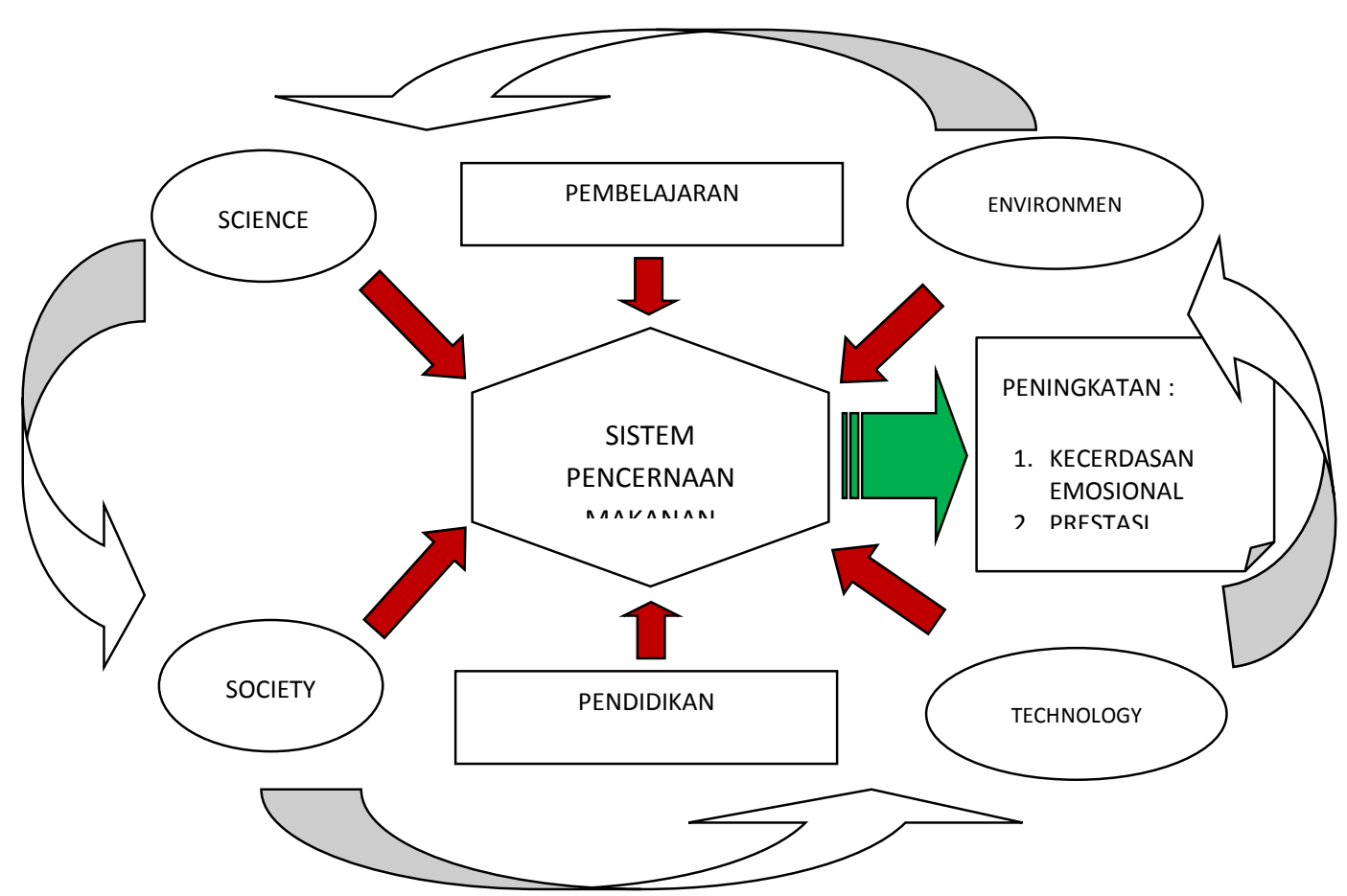

Gambar 4.5. Model Pengorganisasian Pembelajaran Inquiry Bervisi SETS Konsep Sistem Pencernaan Makanan (Modifikasi dari Binadja, 2002)

Berdasarkan Gambar 4.5, perangkat pembelajaran pada konsep sistem pencernaan makanan dikembangkan dengan mengintegrasikan pendidikan kecerdasan emosional dalam kondisi pembelajaran inquiry bervisi SETS yang memfasilitasi siswa untuk meningkatkan kecerdasan emosional dan prestasi prestasi belajar secara optimal.

\section{Pembahasan keefektivan perangkat pembelajaran}

Kriteria efektivitas perangkat pembelajaran ini berdasarkan pencapaian penilaian kecerdasan emosional dan prestasi belajar siswa. Perolehan nilai kecerdasan emosional siswa ternyata lebih tinggi dari kelas kontrol (Gambar 4.2).

Pembelajaran yang mengintegrasikan pendidikan kecerdasan emosional akan memposisikan kembali peran guru sebagai pendidik, bukan hanya sebagai pengajar. Pendidikan kecerdasan emosional secara umum dapat diintegrasikan terutama melalui kegiatan konfirmasi pada setiap awal pembelajaran dan setiap ada kesempatan di sela-sela proses pembelajaran. Aspek kreativitas, motivasi 
diri, dan empati dapat ditingkatkan melalui kegiatan mengajak siswa berbincang tentang SETS dari berbagai macam arah dan titik awal, termasuk kaitannya dengan peningkatan kecerdasan emosional pada aspek tertentu (Binadja, 2002). Melalui diskusi aplikasi konsep terkait ke bentuk teknologi dengan dampaknya bagi kehidupan masyarakat dan lingkungan akan memacu kreativitas dan motivasi siswa untuk mencari alternatif pemanfaatan atau teknologi yang belum ada.

Aspek kemampuan kerja sama dan komunikasi dapat ditingkatkan melalui kegiatan melibatkan siswa secara langsung dalam penggunaan ketrampilan proses melalui kegiatan praktikum, investigasi atau kegiatan penyelidikan ilmu, bekerja sama dalam kelompok, dan mengkomunikasikan hasil dalam forum diskusi (Yager, 2010; Sanjaya, 2008; Garton, 2005). Diantara kelima aspek kecerdasan emosional yang dikembangkan dalam penelitian ternyata yang paling rendah adalah aspek kreativitas dan komunikasi.

Ketercapaian nilai prestasi belajar siswa kelas eksperimen lebih tinggi dibandingkan dengan kelas kontrol (Gambar 4. 4). Hal ini disebabkan penggunaan perangkat pembelajaran inquiry bervisi SETS hasil pengembangan dapat memfasilitasi terjadinya proses pembelajaran berikut: 1). Siswa secara aktif dan menyenangkan (student centered) belajar mencari dan menemukan sendiri jawaban dari suatu permasalahan dengan menggunakan bermacam-macam sumber belajar (Garton,2005; Sanjaya,2008); 2).Siswa melakukan penyelidikan untuk mendapatkan pengetahuan secara integratif, kontekstual, bermakna dan bermanfaat bagi kehidupan siswa dengan menghubung-kaitkan unsur SETS (Ragil, 2011; Binadja, 2002). Kondisi proses pembelajaran tersebut ternyata dapat meningkatkan prestasi belajar siswa. Berdasarkan hasil analisis tersebut, dapat disimpulkan bahwa perangkat pembelajaran efektif digunakan untuk meningkatkan kecerdasan emosional maupun prestasi belajar siswa.

\section{PENUTUP}

\section{Simpulan}

Berdasarkan hasil penelitian dan pembahasan dapat disimpulkan bahwa: 1). Perangkat pembelajaran inquiry bervisi SETS hasil pengembangan sangat valid untuk diterapkan di SMA/MA kelas XI IPA; 2). Perangkat pembelajaran inquiry bervisi SETS hasil pengembangan sangat efektif untuk meningkatkan 
kecerdasan emosional, karena tingkat pencapaian persentase nilai kecerdasan emosional siswa pada kelas eksperimen lebih tinggi dari kelas kontrol; 3). Perangkat pembelajaran inquiry bervisi SETS hasil pengembangan sangat efektif untuk meningkatkan prestasi belajar siswa, karena tingkat ketuntasan belajar, peningkatan prestasi belajar $\mathrm{N}$-gain, dan nilai rata-rata prestasi belajar pada kelas eksperimen lebih tinggi dari kelas kontrol.

\section{Saran}

Saran yang dapat diberikan antara lain: 1). Perlu adanya penelitian lanjutan pengembangan perangkat pembelajaran biologi pada konsep lainya untuk meningkatkan kecerdasan emosional pada aspek tertentu; 2). MGMP kelompok IPA pada tingkat kabupaten/kota perlu melakukan pengkajian terhadap materi-materi pembelajaran yang berpotensi untuk meningkatkan kecerdasan emosional siswa, melalui pembelajaran inquiry bervisi SETS; 3). Perlu adanya usaha pengintegrasian pendidikan kecerdasan emosional dalam dunia pendidikan yang lebih serius untuk suksesnya pelaksanaan Kurikulum 2013.

\section{DAFTAR PUSTAKA}

Agustian, A.G. 2003. ESQ Power. Jakarta: Penerbit Arga

Binadja, A. 2002. Pendidikan Bervisi SETS (Science, Environment, Technology, and Society). Implikasi Kurikulum Berbasis Kompetensi pada Pendidikan Dasar dan Menengah.Makalah. Semarang: Universitas Negeri Semarang

Chaturvedi, A., Yadav, A.K., dan Bajpai, S., 2011. Communicative Approach to Soft and Hard Skills. VSRD International Journal of Bussiness and Management Research, Vol. I (1), 2011, 1-6.

Garton, J. 2005. Inquiry-Based Learning. Willard R-II School District, Technology Integration Academy.

Goleman, D. 2006. Kecerdasan Emosional: Mengapa EQ lebih penting dari IQ. Jakarta: Gramedia Pustaka Utama

Gottman, J. 2001. Kiat-kiat Membesarkan Anak yang Memiliki Kecerdasan Emosional (terjemahan). Jakarta : PT Gramedia Pustaka Utama. 
Ragil, Z. dan S. E. Sukiswo. 2011. Penerapan Pembelajaran Sains dengan Pendekatan Sets pada Materi Cahaya untuk Meningkatkan Hasil Belajar Siswa Kelas V SD. Jurnal Pendidikan Fisika Indonesia, 7(1).

Sanjaya, Wina. 2008. Strategi Pembelajaran: Berorientasi Standar Proses Pendidikan. Jakarta: Kencana.

Sugiyono. 2010. Metode Penelitian Pendidikan Pendekatan Kuantitatif, Kualitatif, dan $R \& D$. Bandung: Alfabeta.

Trianto, 2009. Mendesain Model Pembelajaran Inovatif Progresif. Jakarta: Prenada Media

Widyasari. 2007. Pengaruh Media Pembelajaran dan Kemampuan Berpikir Kreatif Peserta Didik Terhadap Hasil Belajar IPA Terpadu. Jurnal Teknologi Pendidikan Vol. 9. 193-206.

Yager, R.E., dan Akcay, H. 2010. "The advantages of an inquiry approach for science instruction in middle grade". School Scince \& Mathematics. 1110, 5-12 